DOI: https://doi.org/10.24127/ajpm.v10i2.3648

\title{
KEMAMPUAN BERPIKIR KRITIS MATEMATIS MENGGUNAKAN STUDENT TEAM ACHIEVEMENT DIVISION DAN LEARNING TOGETHER
}

\author{
Supratman $^{1 *}$, La Ode Sirad ${ }^{2}$, Andriani Putri $^{3}$ \\ ${ }^{1,2,3}$ Universitas Sembilanbelas November Kolaka, Indonesia \\ *Corresponding author. \\ E-mail: $\quad$ supratmanmathusnkolaka@gmail.com ${ }^{1^{*}}$ \\ laodesirad.usnkolaka@gmail.com ${ }^{2}$ \\ andrianyputri@gmail.com
}

Received 30 March 2021; Received in revised form 09 June 2021; Accepted 28 July 2021

\begin{abstract}
Abstrak
Penelitian ini adalah penelitian eksperimen, dengan tujuan untuk mengetahui: (1) Bagaimana kemampuan berpikir krits matematika siswa pada kelas yang diajar dengan mengunakan model pembelajaran STAD (2) Bagaimana kemampuan berpkir kritis matematika siswa pada kelas yang diajar menggunakan model pembelajran Learning Together (3) Apakah terdapat perbedaan rata-rata kemampuan berpkir kritis matematika siswa yang diajar menggunkan model pembelajaran STAD dan siswa yang diajar menggunakan model pembelajaran Learning Together. Hipotesis dalam penelitian ini adalah terapat perbedaan rata-rata kemampuan berpikir kritis matematika siswa yang diajar menggunakan model pembelajaran STAD dan Learning Together. Populasi dalam penelitian ini adalah seluruh siswa kelas VIII SMP Negeri 2 Latambaga Tahun Ajaran 2018/2019 yang teridiri atas 4 kelas dengan jumlah keseluruhan sebanyak 94 siswa. Pengambilan sampel dilakukan dengan menggunakan cluster random sampling. Pengambilan sampel dilakukan secara random sampling. Teknik analisis data menggunakan statistik deskriptif dan statistik inferensial.Selanjutnya hasil pengujian berdasarkan pengujian hipotesis: dilakukan statistik uji-t (polled varian) diperoleh $t_{\text {hitung }}=1,276>t_{\text {tabel }}=1,702$, yang berarti $H_{0}$ diterima. Dengan demikian, tidak terdapat perbedaan rata-rata nilai secara signifikan anatara kelas eksperiimen I dan kelas eksperimen II.
\end{abstract}

Kata kunci: Kemampuan berpikir kritis; learning together; STAD

\begin{abstract}
This research is an experimental research, with the aim of knowing: (1) How are students 'critical thinking skills in a class taught using the STAD learning model (2) How are students' critical mathematical thinking skills in a class taught using the Learning Together learning model (3) Are There is a difference in the average critical thinking ability of students who are taught using the STAD learning model and students who are taught using the Learning Together learning model. The hypothesis in this study is that there is a difference in the average critical thinking ability of students who are taught using the STAD and Learning Together learning models. The population in this study were all class VIII students of SMP Negeri 2 Latambaga for the 2018/2019 academic year, which consisted of 4 classes with a total of 94 students. Sampling was done using cluster random sampling. Sampling was done by random sampling. The data analysis technique uses descriptive statistics and inferential statistics. Furthermore, the test resuLearning Togethers are based on hypothesis testing: t-test statistics are carried out (polled variant) is obtained $t_{\text {hitung }}=1,276>t_{\text {tabel }}=1,702$, which mean $H_{0}$ received. Thus, there is no significant difference in mean scores between the experimental class I and the experimental class II.
\end{abstract}

Keywords: Critical thinking ability; learning together; STAD

This is an open access article under the Creative Commons Attribution 4.0 International License 
DOI: https://doi.org/10.24127/ajpm.v10i2.3648

\section{PENDAHULUAN}

Ilmu matematika tidak hanya terbatas pada pemecahan masalah dengan menggunakan formula-formula yang kompleks, tetapi merupakan batu pijakan mengenai bagaimana cara seorang berfikir dan menerapkan hal yang dipelajari dalam kehidupan nyata (Ikhsan, Munzir, \& Firia, 2017). Secara umum berpikir kritis adalah penentuan secara berhati-hati dan sengaja apakah menerima, menolak atau menunda keputusan tentang suatu klaim/ pernyataan. berpikir kritis ialah kemampuan untuk menganalisis fakta, mengorganisasi ide-ide, mempertahankan pendapat, membuat perbandingan, membuat suatu kesimpulan, mempertimbangkan argumen, dan kemampuan untuk memecahkan masalah (Kariasa, Ardana, \& Sadra, 2014).

Kemampuan berpikir kritis matematis adalah kemampuan yang penting untuk dimiliki oleh calon guru matematika. Namun ternyata kemampuan berpikir kritis matematis yang dimiliki oleh calon guru matematika masih tergolong rendah. Hal tersebut terlihat dari hasil analisis penelitian ini yang menyimpulkan bahwa calon guru matematika hanya mampu menguasai beberapa indikator kemampuan berpikir kritis matematis (Miatun \& Khusna, 2020). Sedangkan menurut Putri et al., (2020) Pada kenyataannya, kemampuan berpikir kritis siswa belum sepenuhnya diterapkan pada proses pembelajaran. Sekolah justru hanya mendorong siswa untuk memberi jawaban tunggal secara imitatif daripada meminta untuk memunculkan ide baru atau mengevaluasi informasi yang ada. Guru lebih meminta siswa hanya membaca, mendefinisikan, mendeskripsi, dan menyatakan daripada menganalisis, dan menarik kesimpulan, menghubungkan, mengevaluasi ide-ide, mengkritik. Hal ini sejalan dengan hasil observasi yang dilakukan oleh (Indira, Somakim, \& Susanti, 2017) mengatakan bahwa kemampuan berpikir kritis di SMP Negeri 1 Indralaya selatan, pada materi barisan dan deret siswa masih belum mampu memberikan kesimpulan terhadap materi tersebut yang didukung melalui minimnya siswa dalam menyampaikan gagasan dan mencari informasi. Selain itu (Setiawan, 2013) mengatakan bahwa sebagian besar guru yang tidak mau mengubah gaya mengajar dari pemberian ceramah menjadi diskusi dan dialog karena menganggap mengajar dengan menggunakan metode tersebut merupakan tugas yang berat. Pembelajaran dengan menggunakan diskusi dan dialog membutuhkan guru yang meluangkan banyak waktu untuk menciptakan pelajaran "berpikir penuh" yang melibatkan siswa berpikir kritis. Namun hal ini akan menghabiskan waktu yang banyak padahal materi pada kurikulum juga harus diajarkan. Padahal guru juga ditekan untuk meningkatkan skor tes standar siswa. Akibatnya banyak guru yang mengabaikan mengajar berpikir kritis.

Untuk mengatasi masalah tersebut, maka diperlukan model pembelajaran yang dapat membentuk siswa aktif serta mampu mengembangkan konsep dan kemampuan berpikir kritis dalam pemecahan masalah (Jayadipura, 2014). Salah satu model yang diharapkan sesuai dengan hal tersebut adalah model Student Team Achievement Division (STAD) dan Learning Together.

Pembelajaran kooperatif tipe STAD adalah pembelajaran kooperatif dimana siswa belajar dengan menggunakan kelompok kecil yang 
DOI: https://doi.org/10.24127/ajpm.v10i2.3648

anggotanya heterogen dan

menggunakan lembar kegiatan atau perangkat pembelajaran untuk menuntaskan materi pembelajaran, kemudian saling membantu satu sama lain untuk memahami bahan pembelajaran melalui tutorial, kuis satu sama lain dan atau melakukan diskusi (Sapitri \& Hartono, 2015).

Slavin (Irawati, 2016) menyatakan bahwa melalui model Learning Together, proses pembelajarannya melbatkan tanggung jawab individual yang cukup konsisten dalam menunjukkan pengaruh positif yang signifikan, sehingga model Learning Together Terbukti pada pembelajaran individual dari anggota kelompok yang menghasilkan pembelajaran yang lebih baik dibandingkan model individualistik. Selain itu siswa dapat saling bertukar pikiran dengan teman. Hal ini akan membuat kelas lebih hidup dan menyenangkan, sehingga siswa akan lebih serius belajar (Wulandari, 2017). Upaya untuk meningkatkan kemampuan matematik siswa tidak hanya berguna untuk memperoleh hasil belajar yang tinggi, lebih dari itu sebagai bekal bagi siswa untuk menjalani kehidupan bermasyarakat, dan inilah konsep kehidupan matematika dan matematika untuk kehidupan (Maryanti \& Qadriah, 2019).

Oleh karena itu, tujuan penelitian ini untuk mengetahui: (1) Bagaimana kemampuan berpikir krits matematika siswa pada kelas yang diajar dengan mengunakan model pembelajaran STAD (2) Bagaimana kemampuan berpkir kritis matematika siswa pada kelas yang diajar menggunakan model pembelajaran Learning Together (3) Apakah terdapat perbedaan rata-rata kemampuan berpkir kritis matematika siswa yang diajar menggunkan model pembelajaran STAD dan siswa yang diajar menggunakan model pembelajaran Learning Together.

\section{METODE PENELITIAN}

Jenis penelitian ini adalah penelitian True Experiment dengan desain Posttest-Only Control Design. Penelitian ini menggunakan dua model pembelajaran yang berbeda yaitu model pembelajaran STAD yang diberikan pada kelompok eksperimen I dan pembelajaran Learning Together yang diberikan pada kelompok eksperimen II. penelitian ini telah dilaksakan di SMP Negeri 2 Latambaga pada semester ganjil tahun ajaran 2018/2019.

Desain yang digunakan dalam penelitian ini adalah posttest-only control group design. Adapun langkahlangkah dalam peneitian terdiri dari fase perencanaan, fase pelakasanaan, dan fase laporan penelitian, pada fase perencanaan diantaranya merumuskan masalah, mengadakan studi pendahuluan, menentukan sampel penelitian, menyususn rancangan penelitian serta menentukan dan merumuskan hipotesis penelitian, sedangkan pada fase pelaksanaan penenlitian diantaranya pengumpulan data dan analsis data, sedsngkan pada fase laporan penelitian adalah membuat laporan penelitian. Adapun desain penelitian ini sebagai berikut:

\begin{tabular}{|ccc|}
\hline $\mathrm{R}$ & $\mathrm{X}_{1}$ & $\mathrm{O}_{1}$ \\
$\mathrm{R}$ & $\mathrm{X}_{2}$ & $\mathrm{O}_{2}$ \\
\hline
\end{tabular}

Keterangan:

(Samad, 2014)

$\mathrm{R}$ : Random

$\mathrm{X}_{1}$ : Perlakuan pada kelompok kelas eksprimen I

$\mathrm{X}_{2}$ : Perlakuan pada kelompok kelas eksprimen II 
DOI: https://doi.org/10.24127/ajpm.v10i2.3648

$\mathrm{O}_{1}$ : Kemampuan berpkir kritis siswa kelas eksprimen I setelah perlakuan

$\mathrm{O}_{2}$ : Kemampuan berpkir kritis siswa kelas eksprimen II setelah perlakuan.

Populasi dalam penelitian ini adalah seluruh siswa kelas VIII SMP N 2 Latambaga tahun ajaran 2018/2019 yang keseluruhan siswanya berjumlah 94 siswa yang terbagi dalam 4 kelas, terdiri dari kelas $\mathrm{VIII}_{\mathrm{A}}, \mathrm{VIII}_{\mathrm{B}}$, VIII $\mathrm{C}$, dan VIII $_{D}$. dengan menggunakan Cluster Sampling dengan jumlah sampel sebanyak 50 Orang Siswa.

Tabel 1. Jumlah Populasi Siswa Kelas VIII SMP N 1 Latambaga

\begin{tabular}{ccc}
\hline No. & Kelas & Jumlah \\
\hline 1 & VIII $_{\mathrm{A}}$ & 25 \\
\hline 2 & VIII $_{\mathrm{B}}$ & 25 \\
\hline 3 & VIII $_{\mathrm{C}}$ & 25 \\
\hline 4 & VIII $_{\mathrm{D}}$ & 19 \\
\hline Jumlah Siswa & 94 \\
\hline
\end{tabular}

Uji hipotesis dilakukan dengan ujit beda dua sampel berpasangan dengan syarat data berdistribusi normal dan memiliki varians sama yang disebut dengan Independent Sample t-test.

$$
t=\frac{\overline{X_{1}}-\overline{X_{2}}}{S_{\text {gabungan }} \sqrt{\frac{n_{1}+n_{2}}{n_{1} \cdot n_{2}}}}
$$

Dengan:

$$
S_{\text {gabungat }}=\sqrt{\frac{\left(n_{1}-1\right) S_{1}^{2}+\left(n_{2}-1\right) S_{2}^{2}}{n_{1}+n_{2}-2}}
$$

(Ariawan, 2013)

Dengan derajat bebas $(v)=n_{1}+n_{2}-2$ dengan:

$$
t: \text { harga uji statistik }
$$

$\bar{X}_{1}$ : rata - rata posttest siswa kelas eksperimen I

$\bar{X}_{2}$ : rata - rata posttest siswa kelas eksperimen II

$n_{1}$ : banyak sampel kelas eksperimen I

$n_{2}$ : banyak sampel kelas eksperimen II

$s_{1}^{2}$ : variansi data kelas eksperimen I

$s_{2}{ }^{2}$ : variansi data kelas eksperimen II

Kriteria pengujiannya : "Tolak $H_{0}$, jika

$t_{\text {hitung }}>t_{\text {tabel }}$ dalam hal lain $H_{0}$ diterima

jika $t_{\text {hitung }}<t_{\text {tabel }}$ dengan taraf signifikan $\alpha=0,05$

\section{HASIL DAN PEMBAHASAN}

Lembar Observasi guru digunakan untuk melihat, apakah guru dapat melaksanakan proses pembelajaran sesuai dengan sintaks yang ada dalam model pembelajaran STAD dan Learning Together. Hasil Observasi tersebut disajikan pada Tabel 2.

Tabel 2. Hasil lembar observasi aktivitas guru

\begin{tabular}{ccc}
\hline $\begin{array}{c}\text { Pertemu- } \\
\text { an }\end{array}$ & \multicolumn{2}{c}{ Keaktifan Guru } \\
\hline & $\begin{array}{c}\text { Kelas } \\
\text { Eksperimen I }\end{array}$ & $\begin{array}{c}\text { Kelas } \\
\text { Eksperimen II }\end{array}$ \\
\hline I & $86,36 \%$ & $86,67 \%$ \\
\hline II & $90,90 \%$ & $93,33 \%$ \\
\hline III & $95,45 \%$ & $93,33 \%$ \\
\hline Rata-rata & $90,90 \%$ & $91,11 \%$ \\
\hline
\end{tabular}

Berdasarkan hasil lembar observasi aktivitas guru pada Tabel 2 diperoleh bahwa persentase rata-rata keaktifan guru dalam setiap pertemuan mengalami peningkatan baik menggunakan model kooperatif STAD pada Eksperimen I, maupun menggunakan model kooperatif Learning Together pada Eksperimen II. Persentase tersebut menunjukkan bahwa 
DOI: https://doi.org/10.24127/ajpm.v10i2.3648

bahwa setiap pertemuan guru telah mengikuti langkah-langkah pembelajaran sesuai dengan model pembelajaran STAD dan model pembelajaran Learning Together.

Tabel 3. Hasil lembar observasi aktivitas siswa

\begin{tabular}{ccc}
\hline \multirow{2}{*}{$\begin{array}{c}\text { Pertemu } \\
\text { an }\end{array}$} & \multicolumn{2}{c}{ Keaktifan Siswa } \\
\cline { 2 - 3 } & $\begin{array}{c}\text { Kelas } \\
\text { Eksperimen I }\end{array}$ & $\begin{array}{c}\text { Kelas } \\
\text { Eksperimen II }\end{array}$ \\
\hline I & $70,67 \%$ & $68,33 \%$ \\
\hline II & $80 \%$ & $76,67 \%$ \\
\hline III & $88 \%$ & $90 \%$ \\
\hline Rata-rata & $79.55 \%$ & $79.11 \%$ \\
\hline
\end{tabular}

Berdasarkan hasil lembar observasi aktivitas siswa pada Tabel 3 diperoleh bahwa persentasi nilai ratarata aktivitas siswa dalam proses pembelajaran menggunakan model pembelajaran STAD sebesar $79.55 \%$ dan rata-rata siswa dalam proses pembelajaran menggunakan model Learning Together sebesar $79.11 \%$. Skala tersebut menunjukkan bahwa aktifitas siswa tergolong baik atau dengan kata lain siswa aktif saat proses pembelajaran.

Tabel 4. Hasil Analisis Deskriptif

\begin{tabular}{ccc}
\hline Analisis & $\begin{array}{c}\text { Kelas } \\
\text { Eksperimen } \\
\text { I }\end{array}$ & $\begin{array}{c}\text { Kelas } \\
\text { Eksperimen } \\
\text { II }\end{array}$ \\
\hline $\begin{array}{c}\text { Banyak } \\
\text { Data }\end{array}$ & 25 & 25 \\
\hline Rata-rata & 76,94 & 71,686 \\
\hline Varians & 128,53 & 226,848 \\
\hline $\begin{array}{c}\text { Standar } \\
\text { Deviasi }\end{array}$ & 11,337 & 15,0614 \\
\hline
\end{tabular}

Berdasarkan hasil analisis deskriptif pada Tabel 4, diperoleh nilai rata-rata hasil belajar matematika siswa yang diajar dengan menggunakan model pembelajaran STAD (kelas eksperimen I) sebesar 76,94 dan nilai rata-rata hasil belajar matematika siswa yang diajar dengan menggunakan model pembelajaran Learning Together (kelas ekspermen II) sebesar 71,686. Ini menunjukkan bahwa rata-rata kemampuan berpikir kritis matematika dalam pengajaran SPLDV untuk kelas ekperimen I lebih tinggi atau lebih baik dibanding rata-rata kemampuan berpikir kritis matematika untuk kelas eksperimen II.

\section{Hasil Analisis Inferensial}

1. Uji Normalitas

Uji normalitas data dalam penelitian ini menggunakan statistik uji Kolmogorof-Smirnov. diperoleh nilai $D_{\text {hitung }}=0,206$ yang dilihat dari Most Extreme Absolute pada kelas STAD lebih kecil dari pada $D_{\text {tabel }}=0,264$ dan nilai $D_{\text {hitung }}=0,250$ yang dilihat dari Most Extreme Absolute pada kelas Learning Together lebih kecil dari pada $D_{\text {tabel }}=0,264$, sehingga dapat disimpulkan bahwa data sampel pada kelas eksperimen I yang diajar dengan model pembelajaran STAD dan eksperimen II yang diajar dengan model Learning Together berdistribusi normal.

2. Uji Homogenitas

Uji homogenitas dilakukan dengan menggunakan uji $\mathrm{F}$, hal ini dilakukan untuk melihat kesamaan varians sampel. Berdasarkan analisis yang dilakukan diperoleh

$$
\begin{aligned}
& F_{\text {hitung }}=1,7648, F_{\text {tabel }}=1,9554 . \text { Karena } \\
& F_{\text {hitung }}=1,7648<F_{\text {tabel }}=1,9554 \text { maka } \\
& \text { dapat disimpulkan data memiliki } \\
& \text { varians yang sama atau homogen }
\end{aligned}
$$

3. Uji Hipotesis

Berdasarkan uji prasyarat yang dilakukan, diperoleh hasil data berdistribusi normal dan homogen maka pengujian hipotesis menggunakan t-test 
DOI: https://doi.org/10.24127/ajpm.v10i2.3648

Polled Varian . Berdasarkan hasil analisis uji hipotesis dengan menggunakan uji $\mathrm{t}$ diperoleh $t_{\text {hitung }}=1,276$ dan

$t_{\text {tabel }}\left(\alpha=0,05 ; d k=n_{1}+n_{2}-2=48\right)=1,702$

Karena $t_{\text {hitung }}=(1,276)<t_{\text {tabel }}(1,702)$

maka $\mathrm{H}_{0}$ diterima dengan kata lain tidak terdapat perbedaan rata-rata nilai secara signifikan antara kelas ekspermen I dan kelas eksperimen II.

Salah satu model yang dapat meningkatkan kemampuan berpikir kritis adalah STAD dan Learning Together, Pada kelas yang menggunakan model pembelajaran STAD, guru memberikan materi yang disajikan dalam bentuk diskusi, siswa diberikan permasalahan yang berkaitan dengan masalah dalam kehidupan sehari-hari dan berhubungan dengan persamaan linear dua variabel kemudian dikelompokkan menjadi beberapa kelompok. Setiap kelompok diberikan LKS sebagai bahan diskusi masingmasing kelompok, selanjutnya masingmasing perwakilan kelompok mempresentasikan hasil diskusi dan kelompok lain menanggapi, kemudian guru memberikan kuis individu untuk mengukur pemahaman masing-masing siswa. Pada kelas ekspermen II menggunakan model pembelajran Learning Together, yang dalam proses pembelajarannya menggukan metode diskusi, setiap kelompok dibentuk terdiri dari 4 orang siswa yang bersifat heterogen, selanjutnya setiap kelompok di berikan LKS sebagai bahan diskusi, setelah itu masng-masing perwakilan kelompok mempresentaskan hasil didepan kelompok lain yang akan menanggapnya.

Pada setiap pertemuan, pada kelas eksperimen I maupun kelas ekspermen II peneliti diamati oleh observer yang bertugas mengamati bahwa peneliti melaksanakan pembelajaran sesuai dengan RPP. Pada kelas yang diajar menggunakan model pembelajaan STAD jumlah nilai hasil posttest yang diperoleh yaitu 1948.4 dengan jumlah siswa sebanyak 25 siswa, rata-rata kelas yaitu 76,94 serta standar deviasi dan varians masing-masing 11,337 dan 128,53 .

Kelas yang menggunakan model pembelajaran Learning Together jumlah nilai hasil posttest yang diperoleh yaitu 1832.1 dengan jumlah siswa sebanyak 25 siswa, rata-rata kelas yaitu 71,686 serta stadar deviasi dan varians masingmasing 15,0614 dan 226,848. Dari data tersebut menunjukkan bahwa model pembelajaran STAD dan dan model pembelajaran Learning Together tidak terdapat perbedaan rata-rata kemampuan berpikir kritis. Hal ini sejalan dengan teori Slavin (Irawati, 2016) mengemukakan bahwa model pembelajaran Learning Together adalah pembelajaran yang melibatkan siswa yang bekerja dalam kelompokkelompok yang beranggotakan 4 atau 5 yang bersifat heterogen. sedangkan menurut Slavin (Elida, 2016) STAD adalah adalah salah satu model pembelajaran yang cukup sederhana, siswa ditempatkan dalam tim belajar beranggotakan 4-5 orang, guru menyajikan pelajaran kemudian siswa bekerja dalam tim untuk memastikan bahwa seluruh anggota tim menguasai pelajaran tersebut, akhirnya seluruh siswa dikenai kuis tentang materi itu dengan catatan saat kuis tidak boleh saling membantu. Dari kedua teori tersebut nampak bahwa masing-masing memiliki keunggulan sehingga tidak terdapat perbedaan rata-rata kemampuan berpikir kritis siswa. Selain itu menurut (Farokatin, Kusmaryono, \& Aminuddin, 2019) menyatakan bahwa metode Learning Together adalah salah 
satu metode pembelajaran yang relevan. Karena mampu untuk memudahkan pembagian tugas dan memudahkan siswa belajar melaksanakan tanggung jawab sebagai anggota kelompok. Sehingga dapat diterapkan untuk semua mata pelajaran dan tinggkat kelas. Jadi sangat relevan untuk membantu guru maupun siswa dalam mencapai tujuan pembelajaran yang diharapkan.

Kontribusi hasil penelitian (Karim, 2015) menggunakan model pembelajaran jucama kemampuan berfikir kritis siswa khususnya dalam pembelajaran matematika adalah 1) memberikan masalah kontekstual sebagai sarana konflik menemukan konsep, prosedur, strategi dan aturan matematika, 2) memberikan bantuan dalam bentuk scaffolding secara tidak langsung untuk memicu terjadinya interaksi antar sesama siswa, siswa dengan guru, siswa dengan konteks masalah, dan siswa dengan lingkungan sehingga siswa memiliki kemampuan merefleksikan tindakan yang diambil, 3) memahami kesalahan yang dibuat oleh siswa, dan 4) memperhatikan sinkronisasi kemampuan berpikir kritis sebagai pengembangan kecerdasan kognitif dan emosional siswa. Hal ini sejalan dengan hasil penelitian dari (Elida, 2016) mengatakan bahwa pembelajaran matematika menggunakan model pembelajaran kooperatif tipe STAD dapat dijadikan suatu alternatif bagi guru dalam melaksanakan proses belajar mengajar selain itu memotivasi siswa untuk mendorong dan saling membantu siswa dalam menguasai keterampilan atau pengetahuan yang disajikan oleh guru.

\section{KESIMPULAN DAN SARAN}

Berdasarkan hasil analisis dan pembahasan, maka kesimpulan dalam penelitian ini adalah Kemampuan berpikir kritis matematika siswa kelas VIII $_{B}$ yang diajar dengan menggunakan model pembelajaran STAD yang terdiri dari 25 siswa dengan nilai mean sebesar 76,94, varians sebesar 128,53 dan standar deviasi 11,337, Kemampuan berpikir kritis matematika siswa kelas VIII $_{C}$ yang diajar dengan menggunakan model pembelajaran Learning Together yang terdiri dari 25 siswa dengan nilai mean sebesar 71,686, varians sebesar 226,848 dan standar deviasi 15,0614, sehingga tidak terdapat perbedaan ratarata kemampuan berpikir kritis pada kelas yang diajar menggunakan model pembelajaran STAD dan kelas yang diajar menggunakan model pembelajaran Learning Together.

Berdasarkan penelitian yang telah dilakukan, maka diharapkan kepada guru-guru khususnya guru pelajaran matematika jangan hanya menerapkan satu model atau metode saja dalam pembelajaran agar siswa tidak merasa jenuh dan untuk lebih meningkatkan kemampuan berpikir kritis siswa terhadap mata pelajaran matematika yang diajarkan, selain itu kepada peneliti selanjutnya, diharapkan untuk mengembangkan penelitian ini agar siiswa lebih mudah memahami materi yang diajarkan sehingga hasil belajarnya semakin meningkat.

\section{DAFTAR PUSTAKA}

Ariawan, R. (2013). Penerapan Pendekatan Pembelajaran Visual Thingking Disertai Aktivitas Quick On The Draw untuk Meningkatkan Kemampuan Pemecahan Masalah dan Komunikasi Matematis Siswa. Tesis UPI Bandung. Tidak Dipublikasikan.

Elida, E. (2016). Penerapan Model pembelajaran Kooperatif tipe STAD Pada pemebalajaran 
DOI: https://doi.org/10.24127/ajpm.v10i2.3648

Matematika untuk meningkatkan kemampuan berfikir kritis matematis siswa SMP 6 Bandung. Skripsi Universitas Pasundan. Tidak Dipublikasikan.

Farokatin, A., \& dkk. (2019). Pengaruh Aktivitas Belajar Siswa Dalam Learning Together Terhadap Kemampuan Berpikir Kritis. Prosiding (Seminar Nasional Mahasiswa). Universitas Islam SuLearning Togetheran Agung, 15-22.

Ikhsan, M., \& dkk. (2017). Kemampuan Berfikir Kritis dan Metakognisi Siswa dalam menyelesaikan masalah matematika melalui pendekatan Problem Solving. AKSIOMA: Jurnal Program Studi Pendidikan Matematika, 6(2), 234-245.

Indira, T., \& dkk. (2017). Kemampuan Berpikir Kritis Siswa SMP Melalui Pendekatan Matematika Reaistik Indonesia. Histogram: Jurnal Pendidikan Matematika, 1(2), 6175. https://journal.stkip-andimatappa.ac.id/index.php/histogram /article/view/25

Irawati, E. (2016). Keefektivan Model Pembelajaran Learning Together (LT) terhadap hasil belajar matematika siswa kelas IV SDN Gugus Bisma Kecamatan Somagede Kabupaten banyumas. Skripsi Universitas Ngeri Semarang. Tidak Dipublikasikan.

Jayadipura, Y. (2014). Mengukur Kemampuan Berpikir Kritis Matematik. Prosiding Seminar Nasional Matematika STKIP Siliwangi Bandung, 1(al), 125 130.

Kariasa, W., \& dkk. (2014). Pengaruh Model Pembelajaran Kooperatif Tipe STAD Dengan Pendekatan Pemecahan Masalah Terhadap
Kemampuan Berpikir Kritis Matematis Ditinjau Dari Penalaran Formal. E-Journal Program Pascasarjana Universitas Pendidikan Ganesha. Program Studi Matematika, 3, 1-14.

Karim, N. (2015). Kemampuan Berpikir Kritis Siswa Dalam Pembelajaran Matematika Dengan Menggunakan Model Jucama Di Sekolah Menengah Pertama. EDU-MAT Jurnal Pendidikan Matematika, 3(mor 1), 92 - 104.

Maryanti, \& Qadriah. (2019). Peningkatan Kemampuan Berpikir Kritis Dan Logis Matematik Siswa SMK Negeri 1 Sigli Melalui Model Kooperatif Tipe STAD Berbantuan Maple. Jurnal Sains Riset (JSR. Jurnal Sains Riset (JSR), 9(2), 9-16.

Miatun, A., \& Khusna, H. (2020). Kemampuan Berpikir Kritis Matematis Berdasarkan Disposisi Matematis. AKSIOMA: Jurnal Program Studi Pendidikan Matematika, 9(2), 269-278. https://doi.org/10.24127/ajpm.v9i2. 2703

Putri, A., Sumardani, D., Rahayu, W., \& Hajizah, M. N. (2020). Kemampuan Berpikir Kritis Matematis Menggunakan Model Generative Learning Dan Connecting, Organizing, Reflecting, Extending (Core). AKSIOMA: Jurnal Program Studi Pendidikan Matematika, 9(1), 108. https://doi.org/10.24127/ajpm.v9i1. 2617

Samad, A. (2014). Pengaruh Penerapan Pembelajaran Dengan ConceptMapping dan pengetahuan Dasar Matematika Terhadap Kemampuan Pembuktian Matematis Siswa SMA. Tesis UHO Kendari. Tidak Dipublikasikan. 
DOI: https://doi.org/10.24127/ajpm.v10i2.3648

Sapitri \& Hartono. (2015). Keefektifan Cooperative Learning STAD Dan GI Ditinjau Dari Kemampuan Berpikir Kritis Dan Komunikasi Matematis. Jurnal Riset Pendidikan Matematika, 2(2), 283.

Setiawan, J. (2013). Kemampuan berpikir kritis siswa smp dalam pembelajaran bangun ruang sisi datar dengan metode inquiry. EDU-MAT Jurnal Pendidikan Matematika, 1(1).

Wulandari, T. (2017). Pengaruh penggunaan model pembelajaran kooperatif tipe Learning Together terhadap hasil belajar geografi siswa kelas XI IPS di SMA 15 bandar lampung. Skripsi. Fakultas Keguruan dan Ilmu Pendidikan, Universitas Lampung. 